\title{
Ontogeny and Histochemistry of the Zygotic Transfer Cell in Acrotrema ornottianum
}

\author{
M. R. Vijayaraghavan, Sudesh and Nidhi Gautam \\ Department of Botany, University of Delhi, Delhi 110 007, India
}

Accepted January 19,1990

The occurrence of "Wandlabyrinth"/wall ingrowths has been reported in numerous plant cells of diverse exomorphic features. Such wall labyrinth around the zygote is unknown in angiosperms and its presence around the zygote perhaps helps short distance transport of metabolites and consequently aids in embryo nutrition. The present investigation in Acrotrema arnottianum deals with development and histochemistry of wall labyrinth around the zygote called here as the zygotic mantle. The zygote in this taxon reveals the characteristic features of transfer cell.

\section{Material and methods}

Different developmental stages of Acrotrema arnottianum Wight seeds were fixed in $10 \%$ aqueous solution of acrolein (E. Merck) at $0^{\circ} \mathrm{C}$ for 24 hs. Dehydration, infiltration and embedding procedures outlined by Feder and O'Brien 1968 were followed. The sections were cut at $2.0 \mu \mathrm{m}$ thickness using glass knives on a Spencer AO microtome fitted with a special adaptor to hold knives. Histochemical moieties localized here were the insoluble polysaccharides (Feder and O'Brien 1968) and total proteins (Fisher 1968). Photomicrographs were taken on a Carl Zeiss Photomicroscope III.

\section{Results}

\section{Organized female gametophyte}

The ovule is bitegmic, anatropous and becomes campylotropous only after fertilization (Figs. 1A, 2A). The mature embryo sac consists of an egg apparatus (Fig. 1B); three ephemeral antipodal cells and a central cell. The filiform apparatus stains intensely for PAS reaction indicating polysaccharide composition (Fig. 1B). The nucellus is replete with polysaccharide grains.

\section{Post-fertilization events (zygotic mantle)}

The pollen tube discharges the two sperm nuclei into one of the synergids, and they fuse with their respective mates, namely egg and secondary nucleus, resulting in zygote and primary endosperm nucleus. The zygotic wall reveals undulations that extend from the micropylar region and progress all along the sides (Figs. 1C, 2A-C, 4A). These wall labyrinths referred here as "zygotic mantle" show organized depositions and reveal three zones (Fig. 2C). The outermost is prominent and shows wall labyrinth (Fig. 2D, arrow), the middle is very thin whereas the innermost is amorphous. The zygotic mantle has coralloid protuberances that project into the besieging endosperm tissue. The endosperm cytoplasm also undulates and enters into the clefts of the mantle (Figs. 2B-D, 4A). The organogenic part of embryo during progressive stages of proembryo development, pierces through the mantle and emerges. The shrivelled remnants of the mantle adhere to the embryo cell walls (Fig. 2E, arrow). At about 
the globular proembryo stage, the wall labyrinth is restricted towards the lateral wall of the basal suspensor cell that is subjacent to the micropylar end (Fig. 2F).

The wall labyrinth stains intensely for wall polysaccharides. Of the three zones the inner and outer are intensely PAS positive while the middle is feebly stained (Figs. 2C, D). A few polysaccharide grains are present in the zygote cytoplasm. The mantle stains feebly for total proteins (Fig. 3A). The endosperm tissue, however, stains intensely for both, cytoplasmic and nuclear proteins (Figs. 1C, 4B). There is no significant change in protein staining during progressive stages of embryogenesis (Fig. 3B).

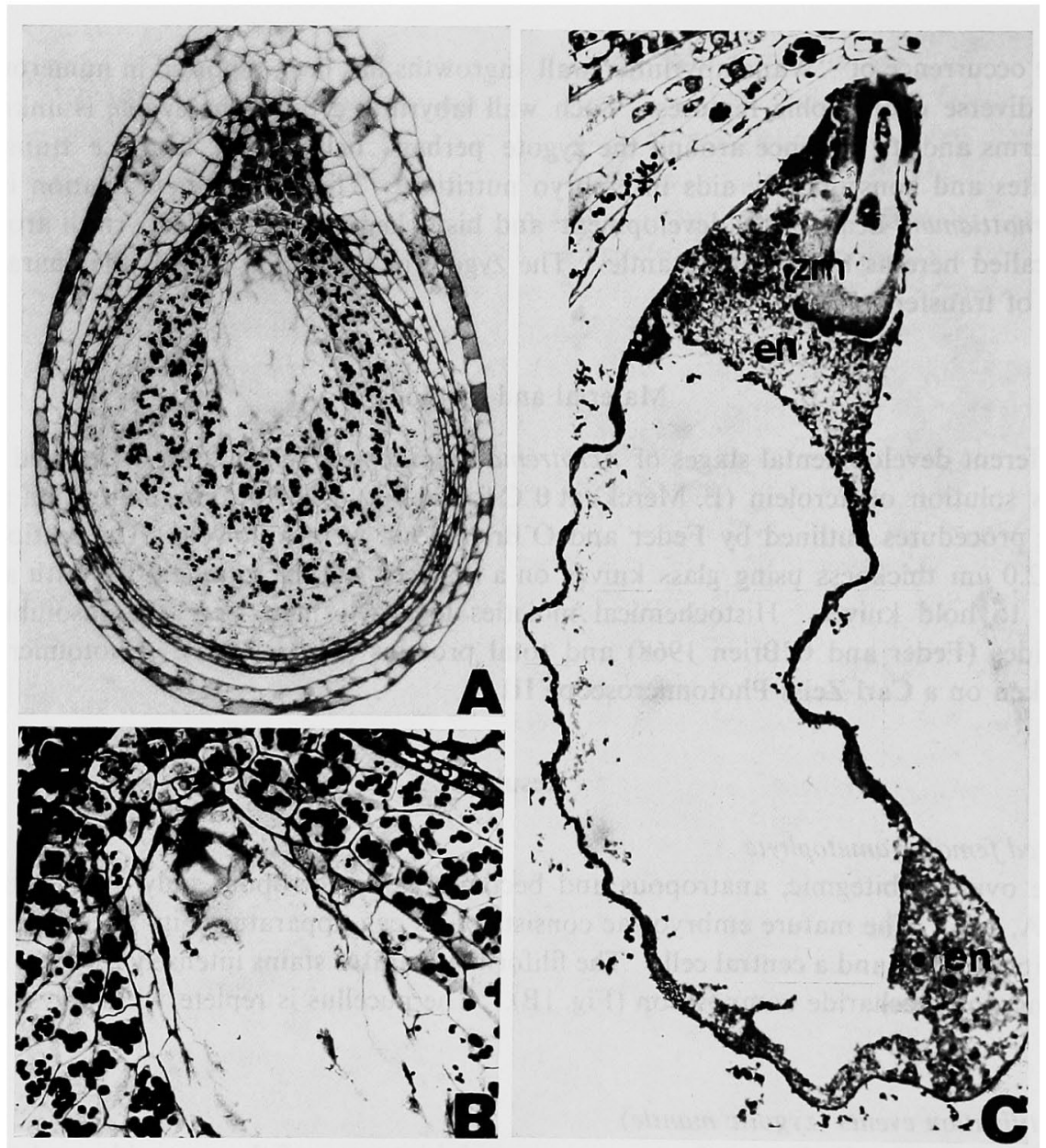

Fig. 1. A, B: Localization of insoluble polysaccharides. C: Localization of insoluble polysaccharides and total proteins. A, longitudinal section of ovule at mature embryo sac stage. $\times 500$. B, female gametophyte showing egg apparatus. $\times 1250$. C, longitudinal section of seed. Zygotic mantle $(\mathrm{zm})$ is intensely PAS positive and endosperm (en) is deeply stained for proteins. $\times 1250$.

\section{Discussion}

The study of zygotic mantle in Acrotrema arnottianum reveals a high degree of structural differentiation, complexity in organization and function. In angiosperms, the zygotic mantle is an unusual feature which has not been reported in any other family of flowering plants and appears esoteric to the family Dilleniaceae. 


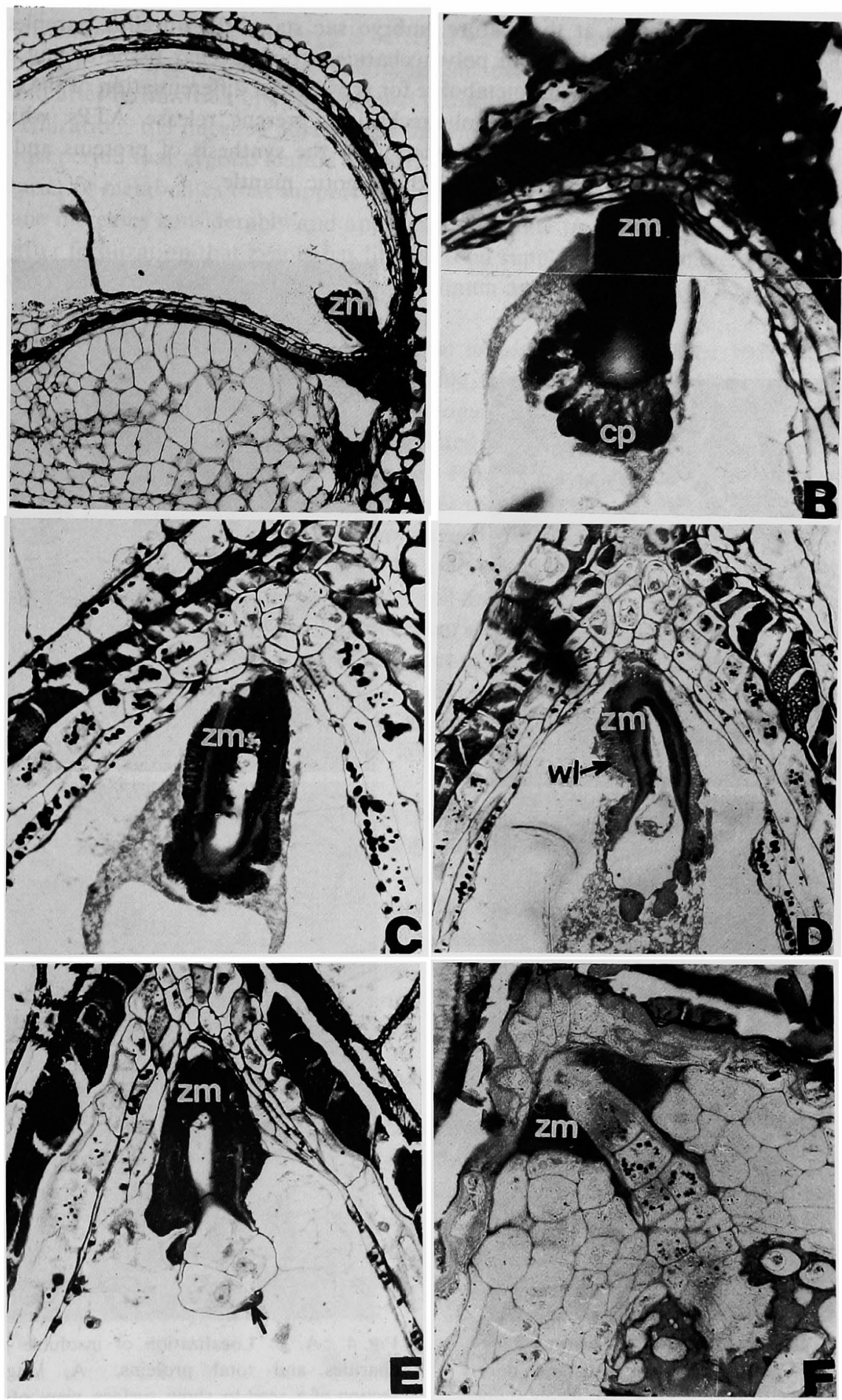

Fig. 2. A-F: Localization of insoluble polysaccharides. A, zygotic mantle in surface view. $\times 500$. B, same, magnified to show deeply stained zygotic mantle $(\mathrm{zm})$. Note coralloid protuberances (cp.). $\times 1250$. C, D, zygotic mantle revealing zonations. Note wall labyrinth (wl) in the outer layer (arrow in D). $\times 1250$. E, intensely stained mantle at early proembryo stage. The shrivelled remnants of the mantle adhere to the embryo cell wall (arrow). $\times 1250$. F, mantle is restricted_only to the sides of a few suspensor cells. $\times 1250$. 
In Acrotrema arnottianum at the mature embryo sac stage, the nucellus is replete with polysaccharide grains. The depletion of polysaccharides from nucellar tissue during embryo maturation indicates utilization of this metabolite for growth and differentiation of the embryo. According to Mahler and Cordes 1971 polysaccharides present release ATPs which are utilized by the growing cells in the form of energy for the synthesis of proteins and RNA. Metabolic processes are at high rate around the zygotic mantle.

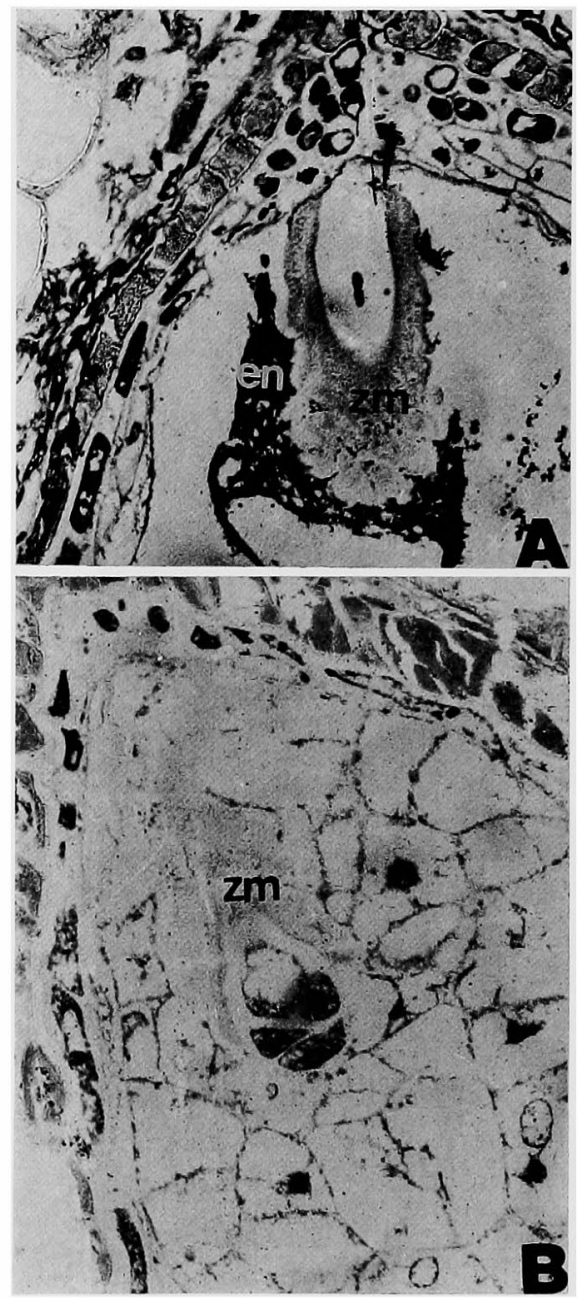

Fig. 3. A, B: Localization of total proteins. A, feebly stained zygotic mantle (zm) and darkly stained endosperm (en). $\times 1250$. B, feebly stained mantle at proembryo stage. $\times 1250$.
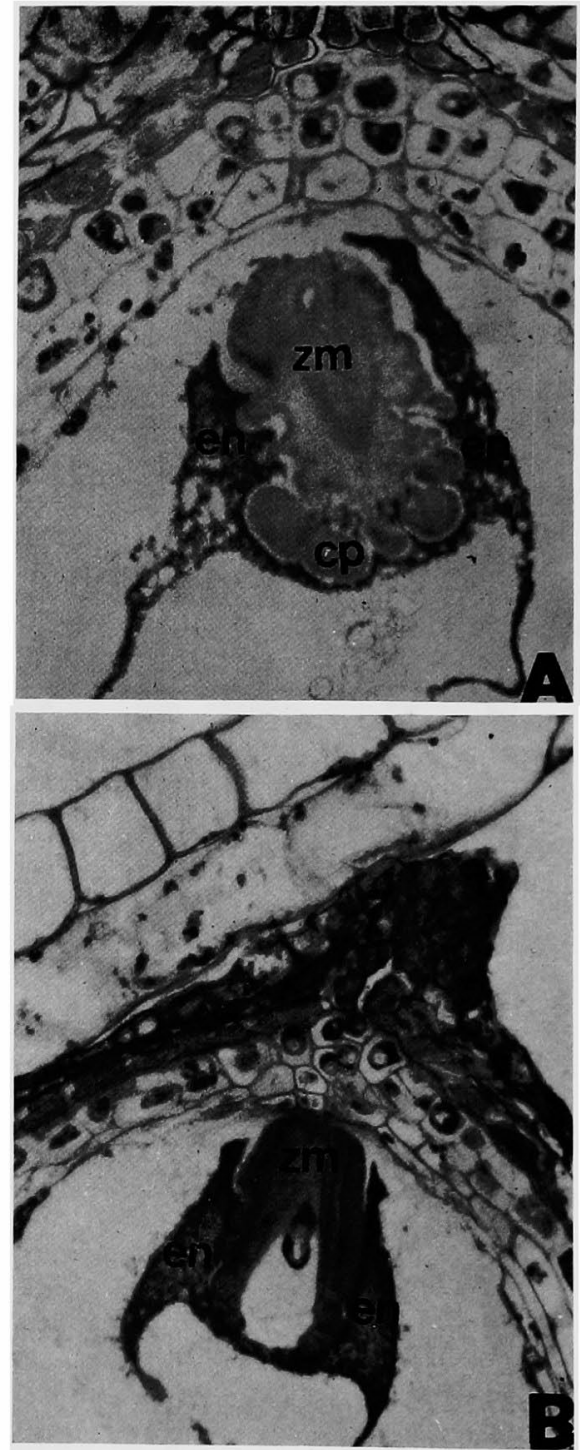

Fig. 4. A, B: Localization of insoluble polysaccharides and total proteins. A, longitudinal section of a seed to show surface view of zygotic mantle $(\mathrm{zm})$ with coralloid protuberances (cp) that stain with PAS and the surrounding protein-rich endosperm (en). $\times 1250$. B, same in sectional view. Endosperm (en) is deeply stained for proteins. $\times 1250$. 
In Acrotrema arnottianum, the egg is bereft of wall ingrowths. After fertilization, elaborate wall labyrinth develop around the enlarging and maturing zygote. The events occurring before and after fertilization offer a congenial nutritional environment to the developing ovule. After fertilization, the nucellus adjacent to the micropyle possesses reserve metabolites. It is during this period that zygotic mantle appears functional and probably contributes significantly as courier of metabolites that support embryogenesis. The absorptive surface of the zygote membrane increases considerably and appears to facilitate transmembrane flux of solutes. It is only after fertilization that zygote has limited food supply. At this stage, zygote wall swells and spreads all over the surface to absorb maximum amount of nutrient supply from the adjacent tissues.

Swamy and Periasamy 1955 in Acrotrema arnottianum and Sastri 1958 in Hibbertia acicularis observed the presence of zygotic mantle. In A. arnottianum (present work) zygotic mantle accrues wall secretions whose morphology befits that of a transfer cell reported in many isolated plant cells, in diverse and unrelated taxa but with one common goal of short distance transport of solutes (see Gunning and Pate 1969, Gunning 1977, Vijayaraghavan et al. 1988). The zygotic mantle plays a significant role in absorption of nutrients from the adjacent tissues. At the globular proembryo stage the mantle is restricted only to the lateral walls of a few embryo suspensor cells. The role of gestatory zygote as it emerges as dicotyledonous embryo, in acting itself as transfer cell and later assigning this role to the suspensor cells in an orderly and programmed ontogenetical sequence, is well exhibited in this herbaceous taxon. The last embryo suspensor cell, adjacent to the micropyle, is bereft of wall ingrowths that usually embellish this cell in many taxa of angiosperms (see Prabhakar and Vijayaraghavan 1983, Vijayaraghavan and Garg 1988). In A. arnottianum (present work) the role of last suspensor cell with the covering of plate-like labyrinth derived and contributed by the zygote wall is noteworthy.

What factors control or induce the differentiation of transfer cell is meagrely understood. What factors operate to produce wall labyrinth around the zygote appears to be even more enigmatic. The form and distribution of wall labyrinth appear to be genetically controlled since they are relatively constant within a species but may vary between species. A strong correlation however exists between the onset of wall labyrinth and existence of solutes to be transported from adjacent tissues. The presence of zygotic transfer cell appears to be the first report and is unique in this herbaceous flowering plant.

\section{Summary}

In Acrotrema arnottianum the zygotic transfer cell stains well for insoluble polysaccharides and feebly for total proteins. The zygotic mantle reveals three zones and the outermost layer of zygotic mantle has PAS positive wall labyrinth. The zygotic mantle acts as a transfer cell with one common goal namely of short distance transport of solutes. During progressive stages of embryo development the basal cell of suspensor has remarkable plate-like labyrinth derived and contributed by the zygote wall.

\section{Acknowledgements}

We thank Dr S. Kedarnath and Dr. N. Sasidharan, Kerala Forest Research Institute, Peechi, Kerala, India for collecting the material. 


\section{References}

Feder, N. and O'Brien, T. P. 1968. Plant microtechnique: Some principles and new methods. Amer. J. Bot. 55: $123-142$.

Fisher, D. B. 1968. Protein staining of ribboned epon sections for light microscopy. Histochemie 16: 92-96.

Gunning, B. E. S. 1977. Transfer cells and their role in transport of solutes in plants. Sci. Prog. Oxf. 64: 539-568.

- and Pate, J.S. 1969. Transfer cells-plant cells with wall ingrowths specialized in relation to short distance transport of solutes-their occurrence, structure and development. Protoplasma 68: 107-133.

Mahler, H. R. and Cordes, E. H. 1971. Biological Chemistry. Harper and Row Inc., New York.

Prabhakar, Kumkum and Vijayaraghavan, M. R. 1983. Histochemistry and ultrastructure of suspensor cells in Alyssum maritimum. Cytologia 48: 389-402.

Sastri, R. L. N. 1958. Floral morphology and embryology of some Dilleniaceae. Botanika Notiser 3: 495510.

Swamy, B. G. L. and Periasamy, K. 1955. Contribution to the embryology of Acrotrema arnottianum. Phytomorphology 5: 301-314.

Vijayaraghavan, M. R. and Garg, Manjulata 1988. Histochemical and ultrastructural aspects of embryosuspensor in Crotalaria retusa and Crotalaria spectabilis. Phytomorphology 38: 53-63.

-, Misra, G. and Saxena, P. 1988. Nutrient transfer during embryonic development of angiosperm plants. Sci. Prog. Oxf. 72: 467-480. 